\title{
PENGARUH STATUS RAWATAN BAYI DI NICU TERHADAP RISIKO DEPRESI PASCASALIN
}

\author{
Yasmina Ema ${ }^{1}$, Rukmono Siswishanto ${ }^{2}$, Shofwal Widad ${ }^{3}$
}

\begin{abstract}
Background: Postnatal depression is a frequent complication after childbirth, approximately occurred 6.5 to $14.5 \%$ in postnatal women. Untreated postnatal depression can have adverse long-term effects. Episodes of depression can be chronic so it will affect the quality of life. Depression that occurs in the mother will affect behavioral, emotional, cognitive, and child interpersonal is in the future. Post partum women whose babies are takenb care in the NICU is believed to have the level of depression, level of anxiety, and trauma symptoms that were higher compared with the women who don't. The occurrence of depression is associated with a variety of factors, including the adaptation with a sick baby, having a baby that isolated in the NICU, and the stress arising from the NICU environment itself.

Objective: To observe the influence of the status of infants in the NICU treatment on the incidence of postnatal depression.

Method: This study used a cross-sectional design. The subjects were post portum women days 14-21 who met the criteria. Subjects were divided into 2 groups, one group of mothers with babies in the NICU and one group of mothers with babies under wentrooming. This study used edinburgh post natal depression scale (EPDS). Statistical test used was chi-square and logistic in regression.

Results and Discussion: The subjects who met the criteria were 144 women. A total of 19 women was suffered from postnatal depression (13.1\%). Educational status of husband and infant admision to NICU giving significant differences on postnatal depression $(p=0.027$ and $p=0.047)$. Infant care in the NICU increased postnatal depression 3.34 times compared rooming in group ( $\mathrm{Cl} 95 \% 1.12$ to 9.99 ).

Conclusion: The proportion of postnatal depression group of mothers with infants treated in the NICU were larger than the rooming in group.
\end{abstract}

Keyword: postnatal depression, neonatal intensive care admission, EPDS

\begin{abstract}
ABSTRAK
Latar Belakang: Depresi pascasalin merupakan salah satu komplikasi yang sering muncul setelah persalinan, terjadi pada $6,5-14,5 \%$ dari wanita pascasalin. Depresi pascasalin yang tidak diobati dapat memiliki efek jangka panjang yang merugikan. Episode depresi ini bisa menjadi kronis sehingga akan mempengaruhi kualitas hidupnya. Depresi yang terjadi pada ibu akan mempengaruhi perilaku, emosi, kognitif, dan interpersonal anak di kemudian hari. Wanita pascasalin yang bayinya dirawat di NICU dipercaya mempunyai tingkat depresi, tingkat kecemasan, dan gejala trauma yang lebih tinggi dibandingkan dengan wanita pascasalin yang bayinya menjalani rawat gabung. Terjadinya depresi ini berhubungan dengan berbagai macam faktor, meliputi adaptasi dengan bayi yang sakit, memiliki bayi yang terisolasi di ruangan NICU, dan stress yang timbul karena lingkungan NICU itu sendiri.

Tujuan: Mengetahui pengaruh status rawatan bayi di NICU terhadap kejadian depresi pascasalin.

Metode: Penelitian ini menggunakan rancangan potong lintang. Subyek penelitian adalah pasien pascasalin hari ke 14-21 yang memenuhi kriteria inklusi. Subyek dibagi menjadi 2, kelompok ibu dengan bayi yang dirawat di NICU dan kelompok ibu dengan bayi rawat gabung. Penelitian ini menggunakan Edinburgh Post Natal Depression Scale (EPDS).

Hasil dan Pembahasan: Subyek penelitian yang memenuhi kriteria berjumlah 144 orang. Sebanyak 19 ibu menderita depresi pascasalin $(13,1 \%)$. Pendidikan suami dan status rawat bayi memberikan perbedaan secara
\end{abstract}

$\overline{{ }_{1,2,3} \text { Bagian Obstetri dan Ginekologi Fakultas Kedokteran Universitas Gadjah Mada }}$ 
bermakna terhadap depresi pascasalin ( $p=0,027$ dan $p=0,047)$. Perawatan bayi di NICU meningkatkan risiko depresi pascasalin sebesar 3,34 kali dibanding perawatan bayi secara rawat gabung (Cl 95\% 1,12-9,99).

Kesimpulan: Proporsi depresi pascasalin kelompok ibu dengan bayi dirawat di NICU lebih besar dibanding kelompok ibu dengan bayi rawat gabung.

Kata kunci: depresi pascasalin, status rawat bayi NICU, skor EPDS.

\section{PENDAHULUAN}

Periode pascasalin merupakan suatu periode yang berpotensi tinggi untuk mengalami gangguan mood. Ada tiga bentuk umum dari penyakit afektif pascasalin yaitu baby blues, depresi pascasalin dan psikosis puerpurium, yang masing-masing berbeda dalam prevalensi, presentasi klinis, dan manajemen.

Depresi pascasalin non psikotik merupakan salah satu komplikasi yang sering muncul setelah persalinan, terjadi sekitar 6,5-14,5\% dari wanita pascasalin. ${ }^{1}$ Pengaruh depresi pascasalin pada ibu, hubungan suami istri, dan anak-anaknya merupakan kondisi yang penting untuk didiagnosis, diobati dan dicegah. $^{2}$

Depresi pascasalin yang tidak diobati dapat memiliki efek jangka panjang yang merugikan. Untuk ibu, episode depresi ini bisa menjadi kronis sehingga akan mempengaruhi kualitas hidupnya. Sedangkan untuk anak-anaknya, depresi yang terjadi pada ibu yang merawatnya dapat berkontribusi untuk masalah perilaku, emosi, kognitif, dan interpersonal di kemudian hari. ${ }^{3}$

Faktor risiko untuk depresi pascasalin meliputi sosiodemografi dan beberapa parameter obstetri. Meskipun faktor risiko yang memprediksi depresi pascasalin telah dipelajari secara rinci pada ibu yang mempunyai bayi sehat, hanya sedikit penelitian mengenai kejadian depresi pascasalin pada ibu yang mempunyai bayi yang dirawat di neonatal intensive care unit (NICU). Ibu dari bayi yang dirawat di NICU diyakini mengalami stres tinggi dibandingkan dengan ibu yang memiliki bayi sehat. Ibu dari bayi NICU memiliki skor EPDS yang lebih tinggi. Ibu yang memiliki skor EPDS lebih tinggi akan memiliki skor kecemasan yang lebih tinggi juga. Para ibu dengan bayi di NICU harus menerima konseling yang tepat selama rawat inap bayi mereka. ${ }^{4}$

Terjadinya depresi ini berhubungan dengan berbagai macam faktor, meliputi adaptasi dengan bayi yang sakit, memiliki bayi yang terisolasi di ruangan NICU, dan stress yang timbul karena lingkungan NICU itu sendiri. ${ }^{5}$

Untuk mendeteksi depresi pascasalin dibutuhkan alat skrining dengan spesifisitas dan sensitifitas tinggi, cepat, mudah diinterpretasikan, dan praktis. ${ }^{2}$ Alat skrining yang digunakan untuk mendeteksi depresi pascasalin adalah kuesioner depresi. Kuesioner depresi yang sering digunakan yaitu kuesioner Beck dan Edinburg Postnatal Depression Scale (EPDS). Kuesioner Beck merupakan kuesioner depresi secara umum. Sedangkan untuk EPDS merupakan kuesioner yang khusus untuk mendeteksi depresi pascasalin.

\section{METODE}

Disain penelitian yang digunakan adalah metode penelitian potong lintang. Sampel diambil dari pasien pascasalin hari ke-14 sampai dengan hari ke-21 yang datang ke poliklinik. Penelitian ini dilakukan pada bulan Januari sampai Maret 2014 di RSUP Dr. Sardjito, RSUD Wates, dan RSUD Banjarnegara.

Didapatkan 144 sampel yang masing-masing dibagi dalam dua kelompok berdasarkan status rawat bayi, yaitu kelompok dengan ibu pascasalin bayi rawat NICU dan kelompok ibu pascasalin dengan bayi rawat gabung. Kriteria inklusi pada penelitian ini adalah kesediaan mengikuti penelitian dan menandatangani informed consent, melahirkan di rumah sakit, pasien pasca-salin hari ke 14 sampai dengan 21 , dan bayi hidup sampai penelitian ini dilakukan. Untuk kelompok rawat NICU kriteria inklusi ditambahkan dengan bayi mengalami 
perawatan di NICU. Sedangkan kriteria eksklusi adalah riwayat gangguan jiwa sebelumnya dan bayi lahir cacat.

Pasien yang memenuhi kriteria inklusi diminta untuk mengisi kuesioner Edinburgh Postnatal Depression Scale (EPDS). Kuesioner ini berisi sepuluh pertanyaan yang bisa digunakan untuk mengidentifikasi pasien dengan risiko depresi pascasalin. ${ }^{1}$ Kuesioner EPDS ini merupakan alat skrining depresi pascasalin yang paling efektif saat ini, mempunyai sensitivitas $86 \%$ dan spesifitas $78 \%{ }^{6}$ EPDS mudah dilaksanakan dan telah terbukti efektif sebagai alat skrining. Subyek penelitian dengan nilai diatas 13 mengindikasikan terjadinya depresi pascasalin.

\section{HASIL DAN PEMBAHASAN}

Selama penelitian didapatkan subyek yang mengalami risiko depresi pascasalin sebanyak 19 orang (13.1\%). Usia subyek penelitian berkisar antara 15 tahun sampai 44 tahun. Jumlah paritas terbanyak adalah multipara sejumlah 87 orang (52\%). Pendidikan suami terbanyak pada kelompok pendidikan $>9$ tahun yaitu 76 orang $(52,6 \%)$, sedang pendidikan istri terbanyak pada kelompok $>9$ tahun yaitu 79 orang $(54,8 \%)$. Dukungan keluarga dan kehamilan yang diinginkan sebesar $97,2 \%$, dan 97,9\%. Mayoritas subyek memberikan ASI eksklusif sebesar 75,6\%, melahirkan secara vaginal sebesar $58,4 \%$, dan sudah menikah sebesar $95.1 \%$.

Tabel 1. Hubungan status rawat bayi terhadap risiko depresi pascasalin

\begin{tabular}{cccccccc}
\hline & \multicolumn{5}{c}{ Depresi } & & \\
\cline { 2 - 5 } Variabel & Ya & & & Tidak & & RP (95\%Cl) & $\boldsymbol{P}$ \\
\cline { 2 - 5 } & $\mathbf{n}$ & $\%$ & $\mathbf{n}$ & $\%$ & & \\
\hline Rawat NICU & 14 & 19,4 & 58 & 80,6 & & $2,8(1,06-7,37)$ & $0,027^{*}$ \\
Rawat gabung & 5 & 6,9 & 67 & 93,1 & & \\
\hline
\end{tabular}

Hasil komparabilitas subyek pada penelitian ini menunjukkan bahwa usia, pendidikan suami, pendidikan istri, pekerjaan istri, pendapatan, status pernikahan, cara persalinan, dukungan keluarga, dan kehamilan yang diinginkan pada kelompok ibu dengan bayi rawat NICU sebanding dengan kelompok ibu dengan bayi rawat gabung kecuali paritas, bayi prematur, dan metode pemberian ASI.

Berdasarkan karakteristik status rawat bayi, risiko depresi pascasalin ibu dengan bayi dirawat di NICU sebanyak 14 orang $(19,4 \%)$, sedangkan pada ibu dengan bayi rawat gabung sebanyak 5 orang (6,9\%). Terdapat hubungan yang bermakna antara status rawat bayi terhadap risiko depresi pascasalin ( $p=0,0027 ; \mathrm{RP} 2,8 ; 95 \% \mathrm{Cl}$ 1,09-9,52).

Terdapat hubungan yang bermakna antara pendidikan suami dengan depresi pascasalin $(p=0,047$; RP 2,42; 95\% Cl 0,97-6,02). Sedangkan untuk variabel yang lain seperti usia, paritas, pendidikan istri, pekerjaan istri, pendapatan, status pernikahan, bayi prematur, dukungan keluarga, kehamilan diinginkan, cara persalinan, dan metode menyusui tidak menunjukkan hubungan yang bermakna dengan depresi pascasalin.

Tidak semua faktor risiko pada analisis bivariat mempunyai hubungan bermakna secara statistik terhadap risiko depresi pasca-salin. Faktor risiko yang berpengaruh adalah status rawat bayi (OR 3,34; 95\% Cl 1,12- 9,99; $p=0,031)$, dan pendidikan suami (OR 2,86; 95\%Cl 1,00-8,15; $\mathrm{p}=0,049$ ). Faktor risiko yang paling dominan mem-pengaruhi depresi pascasalin adalah status rawat bayi.

Kriteria penilaian depresi pascasalin menggunakan kuesioner Edinburghh Postnatal Depression Scale (EPDS). Jika nilai batas pada EPDS lebih dari 13 
maka mengindikasikan terjadinya depresi pascasalin. Hasil penelitian yang melibatkan 144 ibu pascasalin terdapat 19 orang yang menderita depresi pascasalin $(13,1 \%)$. Hal ini sesuai dengan penelitian yang dilakukan sebelumnya yaitu terdapat $6.5-14.5 \%$ dari wanita pascasalin yang mengalami depresi. ${ }^{1}$ Penelitian di Surabaya melaporkan kejadian depresi pascasalin berkisar $22.35 \%{ }^{7}$

Insidensi terjadinya depresi pascasalin mempunyai nilai rentang yang luas berkisar $6.5-24 \%{ }^{8} \mathrm{Hal}$ ini disebabkan oleh rentang waktu pengukuran yang berbeda-beda. Hasil tertinggi untuk skor depresi pascasalin adalah pada minggu kedua sampai kelima pascasalin. Pengukuran yang dilakukan pada minggu pertama pascasalin tidak menggambarkan nilai yang sebenarnya, karena biasanya pada minggu pertama ibu pascasalin masih diliputi euforia oleh kelahiran anaknya.

Faktor risiko terjadinya depresi pascasalin meliputi usia kurang dari 20 tahun, pendidikan istri rendah, pendapatan rendah, multiparitas, tidak menikah, dan kurangnya dukungan keluarga. ${ }^{9}$ Hasil dari penelitian ini menunjukkan bahwa mayoritas yang menderita depresi pascasalin berusia lebih dari 20 tahun (13,1\%). Pendidikan istri yang rendah lebih banyak menderita depresi pascasalin jika dibandingkan ibu yang mempunyai pendidikan tinggi yaitu $16,4 \%$. Wanita multipara mengalami depresi pascasalin lebih banyak dibanding wanita primipara yaitu sebesar $16,1 \%$.

Berdasarkan data yang didapat dari penelitian ini, tidak didapatkan hubungan yang bermakna antara depresi pascasalin dengan usia, pendidikan istri, pendapatan, paritas, pekerjaan istri, status pernikahan, dukungan keluarga, kehamilan yang tidak diinginkan, kelahiran bayi prematur, dan metode pemberian ASI. Hasil ini berlawanan dengan studi sebelumnya dimana usia kurang dari20 tahun, pendidikan istri yang rendah, pendapatan yang rendah, multiparitas, istri yang tidak bekerja meningkatkan risiko terjadinya depresi pascasalin. ${ }^{9}$
Risiko depresi pascasalin pada pendidikan suami kurang dari 9 tahun meningkat 2,42 kali lebih tinggi dibandingkan kelompok dengan pendidikan suami lebih dari 9 tahun. Semakin rendahnya pendidikan suami maka meningkatkan kejadian depresi pascasalin. Pendidikan suami berkorelasi dengan pemahaman tentang konsekuensi yang dihadapi saat istri mengalami kehamilan, proses persalinan, dan setelah persalinan. Jika pendidikan suami semakin rendah maka pemahaman mengenai proses persalinan dan psikologi istri semakin rendah juga sehingga dukungan terhadap istri juga berkurang. Hal ini menyebabkan meningkatkan kejadian depresi pascasalin. ${ }^{9}$

\section{KESIMPULAN DAN SARAN}

Proporsi depresi pascasalin kelompok ibu dengan bayi dirawat di NICU lebih besar dibanding kelompok ibu dengan bayi rawat gabung. Faktor risiko lain yang meningkatkan kejadian depresi pascasalin adalah pendidikan suami kurang dari 9 tahun.

Penelitian lebih lanjut perlu dilakukan dengan metode kohort prospektif untuk mempertajam penegakan diagnosis depresi pascasalin. Lama perawatan bayi di NICU dan jenis pembiayaan yang digunakan perlu dimasukan dalam variabel penelitian. Sebaiknya dilakukan screening untuk depresi pada setiap pasien pascasalin yang mempunyai faktor risiko.

\section{DAFTAR PUSTAKA}

1. Gaynes, B. N., Gavin, N, Meltzer-Brody S, Lohr, K. N., Swinson, T, Gartlehner, G. 2005. Perinatal depression: prevalence, screening, accuracy and screening outcomes. Evid Rep Technol Assess (Summ). 119;1-8.

2. Stewart, D. E. 2011. Depression during pregnancy. N Engl J Med. 365:1605-11.

3. Webster, J, Nicholas, C, Velacot, C, Crindland, N, Fawceet, L. et al. 2010. Quality of life and depression following 1. childbirth: impact of social support. Elsevier /j.midw.05.014. 
4. Yurkadul, Z, Akman, I, Kuscu, K. M, Karabekirogiu, A, Yaylali, G, Demir, F, et al. 2009. Maternal Psychological Problems Associated with Neonatal Intensive Care Admission. International Journal of Pediatrics.59-1359.

5. Carter, J. D., Mulder, R, Bartram, A. F., Darlow, B. A. 2004. Infants in a neonatal intensive care unit: parental response. British Medical Journals, vol 109;F109- F113.

6. Cox, J. L., Holden, J. M., Sagovsky, R. 1996. Detection of postnatal depression: development of the 10item Edinburgh Post Natal Depression Scale. British Journal of Psychiatry, vol 150; 782-786.
7. Wibisono, S, Yamakoto, K, Miyaji, T. 2003. Post natal depression in Surabaya Indonesia. Jstor. 09;912.

8. Parry, B. 2007. Postpartum psychiatric syndrome in Kaplan, H. I\& Saddock, B. J. Comprehensive textbook of psychiatry (Vol VII, pp 1056-1066, 6th ed). Awalvery company. New York

9. Dietz, P. M., Williams, S. B., Callaghan, W. M., Bachman, D. J., Whitlock, E. P., Hornbrook, M. C. 2007. Clinically identified maternal depression before, during, and after pregnancies ending in live births. Am J Psychiatry. 164; 1515- 20. 